\title{
PENGARUH KEPEMIMPINAN DAN KOMUNIKASI TERHADAP KINERJA PEGAWAI PADA KANTOR KECAMATAN BACUKIKI BARAT KOTA PAREPARE
}

\author{
Rusdi \\ Jurusan Administrasi Negara, Universitas Muhammadiyah Sorong \\ Email: rusdicendrawasih@gmail.com
}

\begin{abstract}
ABSTRAK
Penelitian ini bertujuan untuk mengetahui pengaruh kepemimpinan dan Komunikasi terhadap Kinerja Pegawai di Kecamatan Bacukiki Barat Kota Pare-Pare Populasi dari penelitian ini adalah keseluruhan pegawai Negeri Sipil lingkup kantor Kecamatan Bacukiki Barat kota ParePare yang berjumlah 65 orang. Penarikan sampel dengan menggunakan metode purposive sampling. Metode penelitian yang digunakan adalah kuantitatif. Data dikumpulkan dari kuesioner dan wawancara,. Analisis data menggunakan uji validitas, uji realibilitas, uji normalitas, uji linieritas, uji hipotesis yang terdiri dari uji signifikan parsial (Uji-t), Uji Signifikan simultan (Uji-F) dengan taraf signifikan 0,05 dan koefisien determinasi $\left(\mathrm{R}^{2}\right)$ dan analisis regresi linier 0 . Hasil penelitian menunjukkan variabel Kepemimpinan dan komunikasi berpengaruh secara signifikan terhadap variabel kinerja hal ini di tunjukkan dengan nilai $t_{\text {hitung }}>t_{\text {tabel }}$ dan signifikansi $<0,05$ yang artinya Ho ditolak maka Variabel Kepemimpinan dan Komunikasi berpengaruh positif dan signifikan terhadap variabel kinerja Pegawai di Kantor kecamatan Bacukiki Barat Kota Pare-pare.
\end{abstract}

Kata Kunci: Kepemimpinan, Kinerja Pegawai, Kantor Kecamatan.

\section{PENDAHULUAN}

Pegawai yang bekerja di instansi pemerintah merupakan tulang punggung pemerintahan dalam melaksanakan pembangunan nasional. Lebih lanjut dalam penjelasan Undang-Undang Nomor 8 Tahun 1974 tentang pokokpokok kepegawaian dijelaskan pula bahwa kelancaran penyelenggaraan pemerintah dan pelaksanaan pembangunan nasional, terutama tergantung dari kesempurnaan aparatur.

Untuk itu diperlukan adanya pegawai negeri yang penuh kesetiaan dan ketaatan kepada pancasila, UndangUndang Dasar 1945 dan pemerintah,serta yang bersatu padu, bermental yang baik, berwibawa, kuat, berdaya guna,berhasil guna, bersih, berkualitas tinggi, dan sadar akan tanggung jawabnya sebagai unsur aparatur negara dan abadi masyarakat.Menyadari besarnya peran dan fungsi PNS dalam kehidupan berbangsa dan bernegara, maka pemerintah telah menerbitkan berbagai aturan dan ketentuan yang mengatur tentang Pegawai Negeri Sipil, baik yang menyangkut tata hubungan kedinasannya, maupun yang menyangkut sikap dan perilakunya dalam kehidupan sehari-hari.

Dengan semakin banyaknya aturan yang memberikan ikatan dan rambu-rambu kepada Pegawai Negeri, maka seharusnya penampilan dan kinerja para Pegawai Negeri, maka seharusnya penampilan dan kinerja para pegawai dalam melaksanakan tugasnya sudah dapat berlangsung dengan baik.

Namun tidak dapat dihindari karena Pegawai Negari adalah manusia 
biasa dengan karekteristiknya yang unit dan sulit untuk dimengerti secara tuntas, seperti halnya di kantor Kecamatan Bacukiki barat kota Parepare masih sering dijumpai adanya tindakan tindakan melanggar aturan yang sebenarnya dilakukan secara sadar oleh Pegawai Negeri Sipil. Seperti misalnya dengan mengabaikan jam kerja atau melanggar prosedur atau tata kerja yang berlaku.

Hal ini ternyata terjadi juga pada pegawai Negeri pada kantor Kecamatan Bacukiki Barat kota Parepare. Sejumlah Pegawai Negeri bekerja di Kantor Kecamatan Bacukiki Barat kota Parepare. Kerap kali mengabaikan aturan-aturan yang berlaku untuk kepentingan pribadi sehingga kinerja dan efektifitas organisasi dalam usaha pencapaian tujuannya sering kali menjadi terhambat.

Keadaan tersebut bukannya tidak disadari oleh para pegawai akan tetapi karena sudah sering terjadi dalam kualitas dan kuantitas yang tinggi, pada akhirnya dianggap sebagai sesuatu yang lumrah dan wajar.

Ada sejumlah pedoman dasar untuk menjadi pemimpin yang efektif. Pertama, keluwesan. Pemimpin yang luwes memiliki potensi menjadi efektif dalam sejumlah situasi. Kemampuan setiap pemimpin untuk mengubah gayanya pada situasi yang berbeda, akan berbeda-beda. Dengan kata lain, efektivitas pemimpin tergantung pada bagaimana gaya kepemimpinan mereka saling berkaitan dengan keadaan atau situasi. Pemimpin yang sukses adalah pemimpin yang mampu menyelesaikan gaya mereka dengan kebutuhan situasi.

Kedua, berorientasi pada pencapaian. Pemimpin dituntut untuk mampu menetapkan sasaran menantang dan menunjukkan kepercayaan diri bahwa mereka dapat mempercayainya. Dalam hal ini pemimpin adalah seseorang yang menjadi kunci dalam menimbulkan motivasi, kepuasan dan kinerja bawahan yang lebih baik. Mampu mempengaruhi jalur antara perilaku bawahan dan sasaran. Pada batas tertentu, pemimpin adalah seorang pelatih yang merencanakan jalur realistik bagi tim. Bawahan yang mengerjakan tugas pekerjaan tak rutin dan bekerja untuk pemimpin yang berorientasi pada pencapaian merasa lebih yakin bahwa upaya mereka akan menyebabkan kinerja yang lebih baik.

Ketiga, partisipasi. Dalam hal ini pemimpin bertindak untuk meminta, menerima dan menggunakan saran bawahan untuk membuat keputusan. Partisipasi lebih penekankan pada upaya meningkatkan peluang bagi kepuasan pribadi bawahan. Membantu upaya bawahan untuk mencapai sasaran, menolong mengurangi rintangan yang mengecewakan dalam upaya mencapai sasaran memberi penghargaan atas pencapaian sasaran.

Di samping itu, mendorong semangat," menggunakan nilai-nilai, kepercayaan dan kebutuhan bawahan untuk menyelesaikan tugas. Dan mampu melakukan dalam situasional yang sangat cepat berubah atau situasi yang penuh kritis. Dengan kata lain, mampu menampilkan atau menciptakan kepemimpinan yang kharismatik, penuh inspirasi, stimulasi intelektual dan perasaan bahwa setiap bawahan diperhitungkan.

\section{METODE PENELITIAN}

\section{Jenis Dan Pendekatan Penelitian}

Berdasarkan fokus masalah dan tujuan yang hendak dicapai, penelitian ini tergolong ke dalam jenis penelitian survey dan pendekatan kuantitatif, karena penelitian dilakukan pada populasi besar maupun kecil, tetapi data yang dipelajari adalah data dari sampel yang diambil dari populasi tersebut, sehingga ditemukan kejadian-kejadian 
relatif, distribusi dan hubunganhubungan antar variabel dalam Sugiyono, (2007: 7).Dalam penelitian ini terdapat satu variabel dependen yaitu kinerja pegawai (Y) dan dua variabel independen yaitu kepemimpinan (X1), dan komunikasi (X2).

\section{Populasi dan Sampel Penelitian}

Populasi dalam penelitian ini adalah seluruh pegawai negeri sipil lingkup Kantor Kecamatan Bacukiki Barat Kota Parepare dengan masa dinas lima tahun ke atas sebanyak 79 orang. Teknik penarikan sampelnya adalah purposive sampling yaitu 28 PNS kecamatan ditambah 37 sampel PNS Mewakili enam kelurahan jadi sampel $28+37=65$ sampel.Alasan diambilnya pegawai yang mempunyai tahun dinas lima tahun ke atas, karena mereka mengalami langsung dampak kualitas kinerja pegawai Kantor Kecamatan Bacukiki Barat Kota Parepare.

\section{Teknik Pengumpulan Data Penelitian}

Instrumen yang digunakan dalam penelitian ini adalah kuesioner. Dalam penelitian ini kuesioner yang digunakan bersifat tertutup, dimana jawaban sudah tersedia sehingga responden dapat langsung memilih jawaban yang telah disediakan.Metode ini berguna untuk mengumpulkan data dari responden mengenai data responden, tanggapan responden terhadap variabel penelitian yang meliputi: kepemimpinan, Komunikasi, dan kinerja. Pengukuran Instrumen yang dipakai dalam penelitian ini menggunakan skala likert dengan pengisian kuesioner yang disusun dalam bentuk kalimat pertanyaan dan responden diminta mengisi daftar pertanyaan tersebut dengan cara memberi tanda silang (X) pada lembar jawaban kuesioner..Sebelum instrumen ini digunakan untuk mengumpulkan data dalam penelitian ini, terlebih dahulu instrumen diuji coba untuk menguji validitas dan reliabilitas agar memenuhi syarat yang digunakan sebagai alat yang layak digunakan sebagai alat pengumpul data. Instrumen kuesioner dan lembar penilaian oleh atasan dan bawahan yang digunakan untuk mengukur variabel kinerja pegawai (Y), efektivitas kepemimpinan (X1), komunikasi (X2). Ketiga instrument ini dikembangkan sendiri oleh peneliti.Kuesioner, format dari kuesioner ini yaitu menggunakan Likert's Summated Rating (LSR). Tingkat pengukuran yang digunakan adalah jawaban responden diberikan skor lima sampai dengan satu untuk masing-masing alternatif jawaban yang berada dalam rentang dari yang sangat tinggi, tinggi, rendah, sangat rendah.

Uji coba dilakukan pada Kantor Kecamatan Bacukiki Barat Kota Parepare terhadap 65 orang pegawai, dilaksanakan dari tanggal 30 Agustus sampai 30 Oktober 2016. Diambil di lingkup Kantor Kecamatan Bacukiki Barat Kota Parepare. Uji coba ini dimaksudkan untuk mendapatkan suatu alat ukur atau instrument yang memiliki kualitas yaitu memenuhi unsur validitas dan reliabilitas. Untuk analisis validitas butir digunakan analisis korelasi antara skor butir dengan skor total butir dengan menggunakan rumus korelasi product moment.

\section{Uji Validitas}

Validitas adalah suatu ukuran yang menunjukkan tingkat kevalidan/ kesahihan suatu instrumen. Suatu instrumen dikatakan valid apabila mampu mengukur apa yang diinginkannya dan dapat mengungkap data dari variabel yang diteliti secara tepat (Arikunto, 2002).Uji validitas untuk kuesioner yang menggunakan Skala Likert yaitu 1. 2, 3, 4, 5 menggunakan koefesien validitas digunakan koefisien item total 
terkoreksi. Sangat baik, baik, Cukup baik dan Kurang Baik dan tidak baik.Suatu pernyataan dikatakan valid jika nilai koefesien validitas lebih dari atau sama dengan 0,3 (Robert $M$. Kaplan \& Dennis Saccuzo, 1993 dalam Muthalib, 2005:71).

\section{Uji Reliabilitas}

Reliabilitas menunjukkan sejauh mana tingkat kekonsistenan pengukuran dari suatu responden ke responden yang lain atau sejauh mana pernyataan dapat dipahami sehingga tidak menyebabkan beda interpretasi dalam pemahaman pernyataan tersebut. Dengan kata lain reliabilitas menunjukkan sejauh mana suatu hasil pengukuran relatif konsisten apabila pengukuran diulangi lebih dari sekali. Untuk menguji instrumen dengan skala likert digunakan formula umum Alpha Cron Bach.(Sudjana, 1992).

Setelah item pernyataan dihitung untuk mengetahui reliabilitas dengan menggunakan formula umum Alpha CronBach terhadap lima variabel penelitian ternyata semua item pernyataan memenuhi syarat reliabilitas. Dengan kata lain semua item pernyataan tersebut layak digunakan sebagai alat pengumpulan data penelitian.

Setelah instrumen memenuhi syarat validitas dan relialibitas, maka mengedarkan kepada responden. Sebelum mengedarkan lebih dahulu peneliti mengadakan pendekatan dengan Camat dan sekertaris. Dari sekertaris di Kantor Kecamatan Bacukiki Barat Kota Parepare peneliti memperoleh data seluruh pegawai pada dinas tersebut. Kemudian data dipilah berdasarkan; (1) Jabatan, (2) Tahun dinas, (3) Golongan/ ruang, dan (4) Jenis kelamin. Setelah data pegawai diperoleh, maka peneliti memilah dan menentukan sampel berdasarkan tahun dinas, yaitu 5 tahun dinas ke atas yang berjumlah 55 orang. Mereka inilah kemudian diberikan instrumen untuk mengisi, dan kemudian dianalisis untuk melengkapi data penelitian ini.

\section{Uji Asumsi Klasik}

Untuk melaksanakan analisis regresi linier pada uji hipotesis diperlukan beberapa asumsi, diantaranya sampel diambil dari populasi yang berdistribusi normal dan hubungan antar variabel dinyatakan linier. Oleh karena itu, perlu dilakukan uji asumsi data hasil penelitian. Uji asumsi yang diperlukan adalah uji normalitas dan uji linieritas.

\section{1) Uji Normalitas}

Uji normalitas digunakan untuk mengetahui apakah populasi data berdistribusi normal atau tidak. Dalam penelitian ini akan digunakan uji One Sample Kolmogorov-Smirnov dengan menggunakan taraf signifikansi 0,05. Data dinyatakan berdistribusi normal jika signifikansi lebih besar dari 5\% atau 0,05 .

\section{2) Uji Linieritas}

Uji linieritas bertujuan untuk mengetahui apakah dua variabel mempunyai hubungan yang linear atau tidak secara signifikan. Pengujian pada SPSS 20 dengan menggunakan Test for Linearity dengan taraf signifikansi 0,05. Dua variabel dikatakan mempunyai hubungan yang linear bila signifikansi (linearity) kurang dari 0,05 dan $\mathrm{F}$ hitung $<\mathrm{F}$ tabel.

\section{Metode Analisis}

Analisis data dilakukan dengan menggunakan: (1) Analisis deskriptif, digunakan untuk mendeskripsikan faktor kepemimpinan dan faktor komunikasi sebagai variabel bebas dan kinerja pegawai lingkup Kantor Kecamatan Bacukiki Barat Kota Parepare sebagai variabel terikat; (2) Analisis koefisien Pearson correlation dan korelasi ganda, digunakan untuk menguji atau membuktikan hipotesis 
menerima atau menolak hubungan antara variabel bebas dan Variabel terikat yang dinyatakan dalam hipotesis penelitian.Teknik analisa data yang digunakan dalam penelitian ini adalah metode analisis Regresi berganda (Multiple Regression) Sudjana (1999) dengan formulasi sebagai berikut:

$$
\begin{aligned}
& \mathrm{Y}=\mathrm{Bo}+\mathrm{B}_{1} \mathrm{X}_{1}+\mathrm{B}_{2} \mathrm{X}_{2}+\mathrm{e} \\
& \text { Pengujian secara parsial }
\end{aligned}
$$

menggunakan uji-t, untuk menguji pengaruh antara variabel independen secara parsial dengan mengasumsikan bahwa variabel lain dianggap konstan.

\section{Hasil dan Pembahasan}

1. Analisis Variabel Kepemimpinan (X1)

Keberhasilan pemimpin pada umumnya di ukur dari produktivitas dan efektivitas pelaksanaan tugas-tugas yang di bebankan pada dirinya. Dan jika produktivitas naik maka semua tugas dilaksanakan dengan efektif, maka ia disebut sebagai pemimpin yang berhasil atau efektivitas kepemimpinan (kartono, 1992:228). Untuk memperoleh data tentang efektivitas pada Kantor Kecamatan Bacukiki Barat kota Parepare maka peneliti memperoleh data melalui butir pertanyaan yang berjumlah 5 butir pertanyaan yang diedarkan kepada 65 responden, dari butir pertanyaan tersebut setelah dikumpulkan dan diolah secara statistik. Camat bacukiki Barat memiliki keahlian dan keterampilan dalam mengarahkan bawahan menunjukkan bahwa dari 65 responden, sebanyak 21 responden atau $32,3 \%$ yang memilih sangat baik, 39 responden atau $60 \%$ yang memilih baik, 5 responden atau $7,7 \%$ memilih kurang baik. Total skor yang di peroleh 276 , sehingga rata-rata jawaban responden adalah 4,25 termasuk kategori Baik. Dari penjelasan tersebut diketahui bahwa Camat Bacukiki Barat kota Parepare memiliki keahlian dan keterampilan dalam mengarahkan para bawahannya.

Mengenai pernyataan bahwa Camat Bacukiki Barat kota Parepare memberikan contoh untuk patuh pada tata tertib dan peraturan yang belaku menunjukkan bahwa dari 65 responden, setidaknya 8 responden atau $12,3 \%$ memilih sangat baik, 24 responden atau $36,9 \%$ memilih baik, dan 33 responden atau 50,8\% memilih kurang baik. Total skor yang di peroleh 247, sehingga ratarata jawaban responden adalah 3,8, termasuk kategori kurang baik, dapat disimpulkan bahwa Camat Bacukiki Barat Kota Parepare kurang memberikan contoh untuk patuh pada tata tertib dan peraturan yang berlaku.

Frekuensi masing-masing jawaban responden tentang Kepemimpinan camat di Kantor Camat Bacukiki Barat kota Parepare dapat di simpulkan bahwa dari 65 responden, 21 responden atau 32,3\% memilih Sangat baik, dengan pernyataan Pimpinan memiliki keahlian dan keterampilan dalam mengarahkan bawahannya dan 43 responden atau $66,2 \%$ memilih baik, dengan pernyataan Pimpinan memberikan kesempatan pada bawahannya untuk mengembangkan pengetahuan dan keterampilan kerja.

Mengenai pernyataan bahwa Camat Bacukiki Barat kota Parepare memberikan petunjuk kerja yang jelas ini menunjukkan bahwa dari 65 responden, setidaknya 5 responden atau $6,1 \%$ memilih sangat baik, 44 responden atau $67,7 \%$ memilih baik, dan 17 responden atau 26,6\% memilih kurang baik. Total skor yang di peroleh 247, sehingga rata-rata jawaban responden adalah 3,8, termasuk kategori kurang baik, dapat disimpulkan bahwa camat bacukiki kota Parepare kurang memberikan petunjuk kerja yang jelas.

\section{Analisis Variabel Kinerja Pegawai Kantor Kecamatan Bacukiki Barat}


Untuk mengetahui kinerja pegawai pada kantor kecamatan Bacukiki Barat Kota Parepare, maka akan di telusuri melalui frekuensi jawaban Responden terhadap variable kinerja. Tentang indikator menyelesaikan pekerjaan tepat pada waktunya menunjukkan bahwa dari 65 responden, 29 responden atau 44,6\% memilih sangat baik, 32 responden atau 49,2\% memilih baik dan 4 responden atau $6,15 \%$ memilih kurang baik. Total skor yang diperoleh yaitu 285, sehingga rata-rata jawaban responden adalah 4,3 termasuk dalam kategori baik. Dari penjelasan tersebut dapat disimpulkan bahwa secara kuantitas pekerjaan yang diselesaikan tepat pada waktunya oleh pegawai kecamatan bacukiki Barat kota Parepare menunjukkan hal yang memuaskan karena berada pada kategori Baik. pegawai sudah cukup mampu menyelesaikan pekerjaan secara tepat sesuai tenggang waktu yang diberikan. Kemampuan pegawai atau bawahan menyelesaikan tugas atau pekerjaan yang diberikan atau ditugaskan merupakan suatu indikasi bahwa kuantitas kinerja pegawai yang ada di Kantor Kecamatan Bacukiki Barat sudah baik. Hal ini dikarenakan ketepatan waktu menyelesaikan pekerjaan menunjukkan bahwa pegawai sudah cukup mengerti akan tugas tersebut. Mengenaai indikator pegawai memiliki kedisiplinan dan kerapian dalam mengerjakan tugas menunjukkan bahwa dari 65 responden, 11 responden atau $16,9 \%$ memilih sangat baik, 53 responden atau $81,5 \%$ memilih baik dan 1 responden atau 1,5\% memilih kurang baik. Total skor yang diperoleh yaitu 270, sehingga rata-rata jawaban responden adalah 4,2 termasuk dalam kategori baik. Dari penjelasan tersebut dapat disimpulkan bahwa secara kualitas pekerjaan yang dihasilkan pegawai sudah cukup memuaskan.
Kualitas pekerjaan yang dimaksud yakni pegawai memiliki kedisiplinan dan kerapian dalam mengerjakan tugas ini menunjukkan bahwa suatu pekerjaan yang diberikan kepada pegawai atau bawahan dapat dikerjakan secara baik dan maksimal. Mengenai indikator Menjalin kerjasama dengan pimpinan dan rekan kerja menunjukkan bahwa dari 65 responden, 8 responden atau $12,9 \%$ memilih sangat baik, 54 responden atau $83,1 \%$ memilih baik dan 3 responden atau 4,6\% memilih kurang baik. Total skor yang diperoleh yaitu 265, sehingga rata-rata jawaban responden adalah 4,0 termasuk dalam kategori baik. Dari penjelasan tersebut dapat disimpulkan bahwa kerjasama dengan pimpinan dan rekan kerja lingkup kecamatan bacukiki sudah terjalin dengan baik.

Mengenai indikator Pernyataan jika memperoleh suatu informasi penting, maka langsung menyampaikan kepada atasan menunjukkan bahwa dari 65 responden, 13 responden atau $20 \%$ memilih sangat baik, 52 responden atau $80 \%$ memilih baik. Total skor yang diperoleh yaitu 273, sehingga rata-rata jawaban responden adalah 4,2 termasuk dalam kategori baik. Dari penjelasan tersebut dapat disimpulkan bahwa pegawai di Kantor Kecamatan Bacukiki Barat memiliki inisiatif yang cukup tinggi dan cepat merespon akan adanya informasi penting yang harus di ketahui oleh Camat Bacukiki Barat kota Parepare.

Dari hasil penjelasan masingmasing pernyataan kuisioner selanjutnya dibuatkan tabel rangkuman frekuensi jawaban responden mengenai kinerja pegawai di Kantor Kecamatan Bacukiki Barat Kota Parepare.

\section{Uji instrument Penelitian} Uji Validitas

Pengujian validitas dilakukan untuk mengetahui sejauh mana 
kemampuan instrumen penelitian mengukur hal-hal yang seharusnya diukur. Jenis validitas yang digunakan adalah content validity yaitu pengujian yang dilakukan guna membandingkan antara isi instrument dengan isi atau rancangan yang telah ditetapkan.

Pada penelitian ini dilakukan uji signifikansi koefisien korelasi dengan kriteria menggunakan $\mathrm{r}$ kritis pada taraf signifikansi 0,05. Teknik pengujian yang digunakan untuk uji validitas adalah menggunakan korelasi Bivariate Pearson (Produk Momen Pearson) dan Corrected Item-Total Correlation.hasil pengujian validitas Kinerja Pegawai menunjukkan bahwa semua item valid dan dapat digunakan pada tahap analisis.

\section{Uji Realibilitas}

Pengujian realibilitas dalam penelitian ini menggunakan teknik Alfa Cronbach. Pengujian dilakukan kepada 65 orang responden dengan jumlah pernyataan 5 item. Realibilitas instrument dapat diterima apabila memiliki koefisien realibilitas $>0,60$.

Dari hasil perhitungan uji realibilitas pada tabel 4.24 diperoleh nilai Alfa Cronbach untuk semua variabel diatas dari 0,60 yang artinya alat pengumpulan data untuk semua variabel reliabel dan handal.

\section{Uji Linieritas}

Dua variabel dikatakan mempunyai hubungan yang linear bila signifikansi (linearity) kurang dari 0,05 dan $\mathrm{F}_{\text {hitung }}<\mathrm{F}$ tabel. Pengujian pada SPSS dengan menggunakan Test of Linearity dengan taraf signifikansi 0,05 . Berdasrkan tabel $\mathrm{F}$ dengan probabilitas 0,05nilai signifikansi dari output SPSS 20 , diperoleh nilai signifikansi $=0,984$ lebih besar dari 0,05, yang artinya terdapat hubungan linear secara signifikan antara variable kepemimpinan (X1) dengan variable Kinerja (Y). Untuk nilai F dari output di atas, diperoleh nilai $\mathrm{F}$ hitung $=0,134$, dari out put di atas diketahui df 5.58 dengan mencari pada tabel Distribusi tabel nilai $\mathrm{F} 0,05$ di temukan nilai $\mathrm{F}$ Tabel $=2,37$, nilai $\mathrm{F}_{\text {hitung }}=0,134<\mathrm{F}$ tabel $=2,37$ karena nilai $\mathrm{F}$ hitung lebih kecil dari $\mathrm{F}$ tabel maka di simpulkan bahwa terdapat hubungan linier antara variable kepemimpinan (X1) dengan kinerja Pegawai (Y).

nilai signifikansi dari output SPSS 20,0 diperoleh nilai signifikansi $=0,632$ lebih besar dari 0,05, yang artinya terdapat hubungan linear secara signifikan antara variable Komunikasi (X2) dengan variable Kinerja (Y). Untuk nilai $F$ dari output di atas, diperoleh nilai $\mathrm{F}$ hitung $=0,691$, dari out put di atas diketahui df 5.58 dengan mencari pada tabel Distribusi tabel nilai F0,05 di temukan nilai $\mathrm{F}$ Tabel $=2,37$, nilai $\mathrm{F}_{\text {hitung }}=0,691<\mathrm{F}$ tabel $=2,37$ karena nilai $\mathrm{F}$ hitung lebih kecil dari $\mathrm{F}$ tabel maka di simpulkan bahwa terdapat hubungan linier antara variable Komunikasi (X2) dengan kinerja Pegawai (Y).

Analisis

Variabel komunikasi terhadap kinerja pegawai Kecamatan Bacukiki Barat kota Parepare

\section{a. Analisis Regresi Linier Berganda}

Untuk menguji hipotesis dengan keterkaitan atau hubungan antara besarnya variable-variabel kepemimpinan dan komunikasi terhadap kinerja pegawai di kecamatan Bacukiki Barat Kota Parepare maka dilakukan dengan menggunakan analisis regresi linier berganda dengan menggunakan SPSS 20.

$$
\text { model persamaan regresi sebagai }
$$
berikut :

$$
\begin{aligned}
& Y=B o+B_{1} X_{1}+B_{2} X_{2}+e \\
& Y=22.821+176 X_{1}+0.77 X_{2} \\
& \text { Persamaan linier berganda }
\end{aligned}
$$

tersebut dapat diartikan: 
1) Nilai konstanta sebesar 22,821 mempunyai arti bahwa apabila variable bebas (kepemimpinan, komunikasi) bernilai konstan maka nilai variabel terikat (kinerja) sebesar 22,821 .

2) Koefisien regresi variabel kepemimpinan bernilai Positif sebesar 0,176. Hal ini menunjukkan bahwa koefisien beta Positif antara kepemimpinan terhadap kinerja, artinya jika variabel komunikasi bernilai konstan (positif) maka setiap peningkatan satu-satuan dari kepemimpinan akan akan mempengaruhi kinerja sangat tinggi.

3) Koefisien regresi variabel komunikasi internal bernilai positif sebesar 0,77. Hal ini menunjukkan bahwa koefisien beta positif antara komunikasi terhadap kinerja, artinya jika variabel kepemimpinan dan bernilai konstan maka setiap peningkatan satu-satuan dari komunikasi internal akan meningkatkan kinerja.

Terlihat bahwa persamaan tersebut memiliki nilai koefisien regresi linier berganda saling mempengaruhi, artinya jika nilai variable X2 (komunikasi) meningkat atau di tingkatkan maka akan mempengaruhi kinerja.

Dalam pengujian regresi linier berganda terdapat empat macam uji yaitu:

\section{Uji Hipotesis}

\section{1). Uji Koefisien Regresi Secara} Parsial (Uji T)

Uji $t$ digunakan untuk mengetahui apakah variable independen (X1 dan X2) secara parsial berpengaruh terhadap variable dependen (Y) pada tingkat signifikansi a $<0,05$. Hasil uji parsial dapat dilihat pada tabel 36

a. Pengaruh Kepemimpinan terhadap kinerja pegawai.
Dengan mengacu pada nilai $t_{\text {hitung }}$ sebesar 1,999 dengan nilai Sig sebesar 0,044. Hal ini menunjukkan bahwa nilai $t_{\text {hitung }}$ lebih besar dari pada $t_{\text {tabel }}=1,998$ dan nilai Sig 0,044. Dengan demikian $\mathrm{H}_{\mathrm{o}}$ di tolak dan $\mathrm{H}_{1}$. diterima Artinya Variabel kepemimpinan mempunyai pengaruh yang signifikan/Positif terhadap kinerja pegawai kecamatan Bacukiki Barat Kota Parepare.

b. Pengaruh Komunikasi terhadap Kinerja Pegawai

Berdasarkan tabel 4.28 dapat diperoleh nilai $t_{\text {hitung }}$ sebesar $=2,006$ dengan nilai Sig sebesar 0,024. Hal ini menunjukkan bahwa nilai $t_{\text {hitung }}$ lebih besar dari pada $t_{\text {tabel }}=1,999$ dan nilai Sig 0,024. Dengan demikian $\mathrm{H}_{\mathrm{o}}$ di Ditolak dan $\mathrm{H}_{1}$ diterima. Artinya Variabel Komunikasi mempunyai pengaruh yang signifikan/Positif terhadap kinerja pegawai kecamatan Bacukiki Barat Kota Parepare.

\section{2). Uji Koefisien Regresi Secara} Simultan (Uji F)

Uji-F digunakan untuk melihat hubungan antara variabel bebas terhadap variabel terikat secara simultan, yakni dengan melihat nilai signifikansi dan membandingkan nilai $\mathrm{F}$ hitung dengan $F$ tabel. Nilai $F_{\text {hitung }} 8,689$ dapat dilihat pada hasil regresi dan nilai $\mathrm{F}_{\text {tabel }}$ didapat melalui sig. $\alpha=0,05$ dengan $\mathrm{df} 1=\mathrm{k}-1=2-1=1$ dan $\mathrm{df} 2=\mathrm{n}-\mathrm{k}$ $=65-2=63$ maka diperoleh nilai $\mathrm{F}$ tabel $=3,99$. Dapat dijelaskan nilai Sig. 0,000 lebih kecil daripada 0,05 dan F hitung sebesar 8,689 lebih besar dibanding $F_{\text {tabel }} 3,99$. Dengan demikian model regresi antara variabel Kepemimpinan (X1) Komunikasi (X2) terhadap Kinerja Pegawai (Y) dinyatakan fit atau layak (goodness of fit) dan dapat disimpulkan bahwa variabel Kepemimpinan (X1) Komunikasi secara simultan memiliki 
hubungan signifikan dan positif terhadap Kinerja Pegawai (Y).

\section{3). Uji Koefisien Koefisien \\ Determinasi (R2)}

Hasil uji determinasi (R2) dapat dilihat dari nilai koefisien determinasi. Koefisien Determinasi dapat digunakan untuk mengetahui persentase nilai $\mathrm{Y}$ yang dapat dijelaskan oleh garis regresi atau seberapa besar persentase Kinerja Pegawai yang dapat dipengaruhi oleh Kepemimpinan dan Komunikasi. Hasil perhitungan dengan program SPSS 20.0 model summary besarnya Adjusted $\mathrm{R}^{2}=$ $0,70(70 \%)$. Hal ini variabel Kinerja dapat dijelaskan oleh variasi dari kedua variabel independen yaitu Kepemimpinan dan Komunikasi sebesar $70 \%$, sedangkan sisanya sebesar $30 \%$ dijelaskan atau dipengaruhi oleh variabel lain yang tidak diteliti.

\section{Pembahasan}

Sesuai dengan hasil yang telah dijelaskan pada bagian terdahulu maka bagian ini akan dipaparkan tentang efektifitas kepemimpinan (X1), komunikasi pegawai (X2), dan kinerja pegawai (Y) masing-masing sub dapat dipaparkan sebagai berikut :

1. Kepemimpinan (X1)

Berdasarkan tabel 4.8 frekuensi masing-masing jawaban responden tentang Kepemimpinan camat di Kantor Camat Bacukiki Barat kota Parepare dapat di simpulkan bahwa dari 65 responden, 21 responden atau 32,3\% memilih Sangat baik, dengan pernyataan Pimpinan memiliki keahlian dan keterampilan dalam mengarahkan bawahannya dan 43 responden atau 66,2\% memilih baik, dengan pernyataan Pimpinan memberikan kesempatan pada bawahannya untuk mengembangkan pengetahuan dan keterampilan kerja.

2. Komunikasi Pegawai (X2) pernyataan bahwa camat bacukiki Barat kota Parepare memberikan petunjuk kerja yang jelas ini menunjukkan bahwa dari 65 responden, setidaknya 5 responden atau $6,1 \%$ memilih sangat baik, 44 responden atau $67,7 \%$ memilih baik, dan 17 responden atau $26,6 \%$ memilih kurang baik. Total skor yang di peroleh 247, sehingga rata-rata jawaban responden adalah 3,8, termasuk kategori kurang baik, dapat disimpulkan bahwa camat bacukiki Barat kota Parepare kurang memberikan petunjuk kerja yang jelas.

3. Kinerja Pegawai (Y) indikator menyelesaikan pekerjaan tepat pada waktunya menunjukkan bahwa dari 65 responden, 29 responden atau $44,6 \%$ memilih sangat baik, 32 responden atau 49,2\% memilih baik dan 4 responden atau $6,15 \%$ memilih kurang baik. Total skor yang diperoleh yaitu 285, sehingga ratarata jawaban responden adalah 4,3 termasuk dalam kategori baik.

Dari penjelasan tersebut dapat disimpulkan bahwa secara kuantitas pekerjaan yang diselesaikan tepat pada waktunya oleh pegawai kecamatan bacukiki kota Parepare menunjukkan hal yang memuaskan karena berada pada kategori Baik. pegawai sudah cukup mampu menyelesaikan pekerjaan secara tepat sesuai tenggang waktu yang diberikan.

Untuk nilai persamaan regresi $\mathrm{Y}=22.821+176 \mathrm{X}_{1}+0.77$ $\mathrm{X}_{2}$. Dari persamaan tersebut, terlihat bahwa nilai koefisien regresi linier berganda adalah positif, artinya bahwa jika nilai-nilai variabel $\mathrm{X} 1$, dan $\mathrm{X} 2$, meningkat atau ditingkatkan, maka akan mendorong 


\section{meningkatnya kinerja Pegawai Kecamatan Bacukiki Barat kota Parepare. \\ SIMPULAN \& SARAN \\ Kesimpulan}

Berdasarkan hasil penelitian dan pembahasan tentang pengaruh kepemimpinan Camat terhadap kinerja di Kantor Kecamatan Bacukiki Barat Kota Parepare, maka dapat disimpulkan sebagai berikut :

1. Untuk nilai persamaan regresi $\mathrm{Y}=$ $22.821+176 \mathrm{X}_{1}+0.77 \mathrm{X}_{2}$. Dari persamaan tersebut, terlihat bahwa nilai koefisien regresi linier berganda adalah positif, artinya bahwa jika nilai-nilai variabel X1, dan $\mathrm{X} 2$, meningkat atau ditingkatkan, maka akan mendorong meningkatnya kinerja Pegawai Kecamatan Bacukiki Barat kota Parepare.

2. Variabel kepemimpinan berpengaruh positif dan signifikan terhadap kinerja Pegawai, dengan nilai signifikansi $0,044<0,05$ sehingga (H1) diterima. Hal ini menunjukkan bahwa dengan adanya kepemimpinan yang baik dapat mempengaruhi kinerja Pegawai agar mencapai hasil kerja yang maksimal.

3. Variabel komunikasi berpengaruh positif dan signifikan terhadap kinerja Pegawai, dengan nilai signifikansi $0,024<0,05$ sehingga (Ha) diterima. Hal ini menunjukkan bahwa dengan adanya komunikasi yang efektif dapat membangkitkan semangat Pegawai untuk bekerja lebih baik.

4. Dari hasil pengujian secara parsial diketahui bahwa variabel yang berpengaruh dominan adalah variabel kepemimpinan, hal ini dibuktikan dengan nilai koefisien beta sebesar 0,244, dan nilai $\mathrm{t}$ hitung sebesar 1,999 , dengan nilai signifikansi sebesar $0,044<0,05$, jika dibanding dengan nilai t tabel sebesar 1,998, maka $\mathrm{t}$ hitung $>\mathrm{t}$ tabel $(1,999>1,998)$.

\section{Saran}

Berdasarkan keterbatasan tersebut, maka penulis memberikan saran sebagai berikut:

1. Untuk para pemimpin dalam organisasi diharapkan dapat memberikan perhatian yang serius terhadap pengembangan sumber daya manusia aparaturnya. Karena dengan adanya peningkatan dan pengembangan sumber daya ini maka secara langsung maupun tidak langsung akan memberikan kontribusi yang besar bagi kinerja pegawai. Disamping itu, pemimpin dapat pula menciptakan pola hubungan yang baik didalam organisasi yakni antara bawahan dan atasan dan sesama rekan sekerja yang pada akhirnya akan tercipta sistem kerja yang kuat dalam organisasi.

2. Dalam penelitian selanjutnya diharapkan menggunakan variabel yang lebih bervariasi dengan menambah variabel lainnya yang juga memiliki pengaruh terhadap kinerja Pegawai, agar hasil penelitian lebih lengkap dan maksimal.

\section{DAFTAR PUSTAKA}

Achmad, S. Ruky. 2006. Sistem Manajemen kinerja Performance management System Panduan Praktis untuk Merancang dan Meraih Kinerja Prima. Jakarta: PT Gramedia Pustaka Utama.

Adisasmita, Rahardjo, Prof. Dr. M.Ec. 2007. Pendanaan Pemerintah Daerah. Makassar :Seruni Com.

Agung, I Gusti Ngurah, Prof. Ph.D. 2008. Manajemen Penulisan Skripsi, Tesis, dan Disertasi. 
Jakarta : PT. Raja Grafindo Persada.

AH, Prabowo Fahrudin. 2009. Meningkatkan Efektivitas Kepemimpinan, http://massofa. wordpress.com/2009/03/05.

Arifin, Anwar, Prof. Dr. 2007. Ilmu Komunikasi Krisis dan Revolusi. Jakarta : Fakultas Ilmu komunikasi Universitas Persada (UPI)-YAI bekerjsama Pustaka Indonesia.

Arikunto, Suharsimi. 2002. Prosedur Penelitian Suatu Pendekatan Praktis. Jakarta : Rineka Cipta.

Amstein S. 1969. "A Ladder of Citizen Paticipation". Journal of American Institute of Planners, 35(4): 216-224.

Arifin, Anwar, 1988. llmu Komunikasi Sebuah Pengantar Ringkas. Rajawali Pers: Jakarta.

Arikunto, Suharsimi. 2002. Prosedur Penelitian Suatu Pendekatan Praktek. Jakarta: Rineka Cipta.

Bungin, Burhan. 2006. Metodelogi Penelitian Kuantitatif,

Komunikasi,

Ekonomi, dan Kebijakan Publik serta ilmu-ilmu Sosial lainnya. Jakarta: Kencana

Boer, Michael, and Robert A. Ruh. 1991. Employ Grawth Through Performance Manajemen, Apprising Peformance Appraising. A Harvard Businness Review Paperback.

Bennis.Warren and Mische, Michael, 1995. Organisasi Abad 21 (Reinventing melalui Reengineering), Terjemahan ; Irma Andriani Rachmayanti, PT. Pustaka Binaman Pressindo, Jakarta

Cangara, Hafied, H. Prof. Dr. M.Sc. 2008. Pengantar Ilmu Komunikasi. Jakarta : PT. RajaGrafindo Persada.
Chori, Muhammad. 1999. Faktor Individu dan Faktor Lingkungan Kerja Sebagai Pembentuk Perilaku Pengaruhnya terhadap Prestasi Kerja Pegawai.

Dara, Aisyah, 1998, Studi Reformasi Administrasi Perpajakan di Indonesia, Tesis. Yogyakarta: UGM.

Danim, Sudarwan. 2004. Motivasi Kepemimpinan \& Efektivitas Kelompok. Jakarta: Rineka Cipta. Andi (edisi refisi)

Depari, Eduard, Dr. Dr. Colin MacAndrews. 2006. Peranan Komunikasi Massa Dalam Pembangunan. Yogyakarta : Gadjah Mada University Press.

Dharma, Agus. 2004. Manajemen Prestasi Kerja (Pedoman Praktis Bagi Penyelia Untuk Meningkatkan Prestasi Kerja). Jakarta : Rajawali.

Dwiyanto. 1995. Penilaian Kinerja Organisasi Pelayanan Publik. Yogyakarta: Tesis. Fisip UGM.

Edwin A. Locke. 1997. Esensi Kepemimpinan. Jakarta: Mitra Utama.

Effendi, Onong Uchjana. 2001. Ilmu Komunikasi. Bandung : Rosdakarya.

Erza, Rizky Nanda, 2010. PengaruhKepemimpinan, Motivasi, dan Disiplin Kerja Terhadap Kinerja Pegawai PT. Sinar Lestari Di Kota Pekanbaru. Fakultas Ekonomi Universitas Riau.

Gary, Yukl. 2009. Kepemimpinan Dalam Organisasi Edisi Kelima. Jakarta: PT Indeks.

Ghoizali, Imam, 2008. Structural Equation Modeling Metode Alternatif dengan Partial Least 
Square (PLS). Semarang: Badan Penerbit Universitas Diponegara.

Gibson James L. Ivancevich John M and Donnely James H. Jr. 1996. Organisasi Perilaku, Srtuktur dan Proses. Jilid 1, alih bahasa: Nunuk Adiami. Jakarta: Binarupa Aksara.

Gibson, et, Al. 2004. Organisasi Perilaku Struktur Proses. Surabaya : Erlangga.

Gie, The Liang. 2006. Administrasi Perkantoran Modern. Jilid I Yogyakarta : Ray

Handayaningrat, Soewarno, Drs. 1990. Pengantar Ilmu Administrasi dan Manajemen. Jakarta : CV. Haji Masagung.

Handoko, Hani T. 1995. Manajemen. Yogyakarta: BPFE

Harahap, Kristanti Pahlawansjah, 2012. Pengaruh Gaya Kepemimpinan, Komunikasi,Dan motivasi Kerja Terhadap Kinerja Pegawai (StudiPada PT. Bank Tabungan PensiunanNasionalCabang Semarang).Jurnal Dinamika Manajemen.Vol.1 No.1.

Hardjana, M. Agus. Drs. M.Sc. Ed. 2002. Komunikasi Intrapersonal dan Interpersonal. Yogyakarta : Kanisius.

Hartanto, Frans Mardi. 2009. Paradigma Baru Manajemen Indonesia, Menciptakan Nilai dengan Bertumpu pada Kebijakan dan Potensi Insani. Bandung: PT Mizan Pustaka.

Indrawijaya, A.I. 2006. Perilaku Organisasi. Bandung : Sinar Baru.

Kartono, Kartini, Dra. 1990. Pemimpin dan Kepemimpinan Apakah Pemimpin Abnormal Itu? Jakarta : Rajawali Press.

Kotter, Jack. 1991. Strategic Management in Public and
Nonprofit Organizations. New York: Praeger Publishers.

Lestari G, Endang, SH. MM. Drs. MA. Maliki, M.Ed. 2006. Komunikasi Yang Efektif. Jakarta : Lembaga Administrasi Negara Republik Indonesia.

Mangkunegara, A.A.Anwar Prabu. 2007. Manajemen Sumber Daya Manusia Perusahaan. Salemba Infotek. Jakarta.

Mahmud. 2010. Manajemen Kinerja Sektor Publik. Edisi Kedua. Yogyakarta: Unit Penerbit Sekolah Tinggi ilmu Manajemen YKPN.

Martin, M. Andre. F.V. Bhaskara. 2002. Kamus Bahasa Indonesia Millenium. Surabaya : Karina.

Makmur. 2009. Teori Manajemen Stratejik dalam Pemerintahan dan Pembangunan. Bandung: PT Refika Aditama.

Marthin, L. L. and P. M. Kettner. 1996. Measuring the Performance of human Service Program. New Delhi: Sage Publication.

Muthalib, Abdul. 2005. Pengaruh Kebijakan Restrukturisasi Organisasi Perangkat Daerah Terhadap Kinerja Asparatur di Sekretariat Daerah Kabupaten Halmahera Tengah. Tesis. Jatinangor. Program Pascasarjana. Institut Pemerintahan Dalam Negeri. (Tidak dipublikasi).

Moeheriono. 2009. Pengukuran Kinerja Berbasis Kompetensi. Bogor: Ghalia Indonesia.

Moh. Nazir. 2002. Metode Penelitian. Jakarta : Ghalia

Mulyana, Deddy. 2002. ilmu Komunikasi suatu Pengantar. Bandung : Remaja Rosdakarya.

Nasrul, Wathon dan Zulian Yamit. 2005. Pengaruh Faktor Individu, 
Budaya Organisasi dan Perilaku Kerja Terhadap Kinerja Pegawai Di Kantor Pelayanan Pajak Yogyakarta Dua. Jurnal ISSN: 1410-9018. Edisi Khusus on Human esoarses.

Nurudin. 2008. Sistem Komunikasi Indonesia. Jakarta : PT. RajaGrafindo Persada.

Pamudji, S. 2004. Tata Kerja Organisasi. Jakarta : Bina Aksara.

Peraturan Pemerintah Republik Indonesia Nomor 8 Tahun 2003 Tentang Pedoman Organisasi Perangkat Daerah.

Peraturan Pemerintah Republik Indonesia Nomor 41Tahun 2007 Tentang Pedoman Organisasi Perangkat Daerah.

Princes, Z. Helfin. 2008. Manajemen Reformasi Birokrasi. Jogjakarta: Mida Pustaka.

Ralahalu, Karel Albert. 2006. Otonomi Daerah Di Tengah Konflik Merancang Succes Story Implementasi Otonomi Daerah di Provinsi Maluku. Jakarta: Gramedia.

Rakhmat. 2009. Teori Administrasi dan Manajemen Publik. Jakarta: Pustaka Arif.

Rakhmat, Jalaluddin, Drs. M.Sc. 2001. Metode Penelitian Komunikasi Dilengkapi Analisis Statistik. Jakarta : Rosda.

2007 , Metode Penelitian Komunikasi,PT Remadja Rosda Karya , Bandung.

Rauf, Maswadi dan Nasrun, Mappa (ed), 1993. Indonesia dan Komunikasi Politik. Jakarta: PT. Gramedia Pustaka Utama.

Rivai, Veithzal, dan Mulyadi, Deddy. 2010. Kepemimpinan dan Perilaku Organisasi. Jakarta:
Kharisma Putra Utama Offset PT Raja Grafindo Persada.

Robins, $\quad$ Stuart-Kottze. 2006. Performance. London: Prentice. Hall.

Salusu. 1996. Pengambilan Keputusan Stratejik untuk Organisasi Publik dan Organisasi Nonprofit. Jakarta: PT Gramedia Widiasarana Indonesia.

Sedarmayanti, Syarofuddin Hidayat. 2002. Metodologi Penelitian. Bandung : Mandar Mundur

Sedarmayanti. 2008. Manajemen Sumber Daya Manusia Reformasi Birokrasi dan Manajemen Pegawai Negeri Sipil. Bandung: PT. Refika Aditama,

Sedarmayanti. 2000. Restrukturisasi dan Pemberdayaan Organisasi Untuk Melengkapi Dinamika Perubahan Lingkungan. Bandung: Mandar Maju.

Siagian Sondang P, 1987, Organisasi Kepemimpinan dan Perilaku Administrasi. Jakarta: Gunung Agung.

Siagian, P. Sondang. Prof. Dr. MPA. 2006. Manajemen Sumber Daya Manusia. Jakarta : PT. Bumi Aksara.

2003. "Teori dan Praktek Kepemimpinan”, Rineka Cipta., Jakarta.

Sinambela, Lijan Poltak, dkk. 2008. Reformasi Pelayanan Publik Teori, Kebijakan, dan Implikasi. Jakarta: Bumi Angkasa.

Simanjuntak, Payaman J. 2005. Manajemen dan Evaluasi Kinerja. Jakarta: Lembaga Penerbit Fakultas Ekonomi Universitas Indonesia.

Sitanggang, 1997, Ekologi Pemerintahan, Jakarta; Pustaka Sinar Harapan. 
Sugiyono, Prof. Dr. 2010. Metode Penelitian Administrasi Dilengkapi dengan Metode $R \&$ $D$. Bandung : Alfabeta.

----------. 2003, Metode Penelitian Administrasi, CV. Alfabeta, Bandung

Supratiknya, A. Dr. 2006. Komunikasi Antarpribadi Psikologis. Yogyakarta : Kanisius.

—. 2003. Teori dan Praktek Kepemimpinan. Jakarta: Penerbit Rineka Cipta.

-. 2010. Teori dan Praktek kepemimpinan. Jakarta: Rineka Cipta.

Sudjana. 1992, Teknik Analisis Regresi dan Korelasi .Bandung: Tarsito;

Sugiyono. 2007. Metode Penelitian Administrasi dilengkapi dengan Metode $\quad R \& D . \quad$ Bandung: ALFABETA.

Sukengsari, Endah Mawarni, dan Sobirin, Achmad. 2005. Implikasi Restrukturisasi Kelembagaan Terhadap Perubahan Perilaku Pegawai dan Iklim Organisasi (Studi Kasus pada Badan Kesatuan dan Perlindungan Masyarakat Provinsi DIY. Jurnal ISSN: 1410 - 9018. Edisi Khusus on Human esoarses.

Sopiah. 2008. Perilaku Organisasional. Yogyakarta: Penerbit Andi.

Supriyatno, Budi. 2009. Manajemen Pemerintahan (Plus Dua Be/as Langkah Strategis). Jakarta: CV. Madia Brilian.

Thoha, Miftah. 2002. Perilaku Organisasi (Konsep Dasar dan Aplikasinya. Jakarta: PT. Raja Grafindo Persada.

Thoha, Miftah. 2008. Perilaku Organisasi Konsep Dasar dan Aplikasinya. Jakarta : PT. RajaGrafindo Persada.
Undang-undang Nomor 12 Tahun 2008 Tentang Perubahan UU nomor 32 tahun 2004 tentang Pemerintahan Daerah.

Wasistiono, Sadu, 2001, Kapita Selekta Manajemen Pemerintahan Daerah, Jatinangor: Alqaprint.

Wasistiono Sadu. 2003. Kapita Selekta Penyelenggaraan Pemerintah Daerah. Bandung: Fokusmedia,

Wibowo, 2009. Manajemen Kinerja. Jakarta: PT Raja Grafindo Persada, Edisi kedua.

Winardi, J. 2007. Manajemen Perilaku Organisasi. Jakarta: Prenada Media Group.

Winarno, 2004. Kebijakan Publik, Teori, Proses. Dan Studi Kasus. Jakarta: CAPS.

Wiryanto. 2004. Pengantar Ilmu komunikasi . Jakarta : PT. Gramedia Widiasarana Indonesia.

http://www. Bintan-web.id Efektivitas Kepemimpinan. Home. Selasa, 5 Mei 2011). 